\title{
STUDI KOMPARATIF KELAYAKAN USAHATANI CABAI MERAH PADA MUSIM YANG BERBEDA
}

\section{THE COMPARATIVE FEASIBILITY STUDY OF RED CHILI FARMING IN THE DIFFERENT SEASON}

\author{
Betty Rofatin* ${ }^{1}$ Jati Wijaya ${ }^{2}$ \\ ${ }^{1}$ Dosen Jurusan Agribisnis, Fakultas Pertanian, Universitas Siliwangi, Tasikmalaya. \\ ${ }^{2}$ Jurusan Agribisnis, Fakultas Pertanian, Universitas Siliwangi, Tasikmalaya \\ *E-mail corresponding: bettyrofatin@yahoo.com
}

\begin{abstract}
ABSTRAK
Penelitian ini bertujuan untuk mengetahui biaya, pendapatan dan kelayakan usahatani cabai merah yang ditanam pada musim hujan dan musim kemarau di kelompok tani Tunas Jaya Desa Sukagalih Kecamatan Sukaratu Kabupaten Tasikmalaya. Metode penelitian yang digunakan dalam penelitian ini adalah studi kasus pada kelompok tani Tunas Jaya di Desa Sukagalih Kecamatan Sukaratu Kabupaten Tasikmalaya. Hasil penelitian menunjukkan besarnya biaya yang dikeluarkan untuk usahatani cabai merah yang ditanam pada musim hujan adalah Rp 47.718.410,00 per Hektar per musim tanam dan pada musim kemarau Rp 40.832.250,00 per Hektar per musim tanam. Pendapatan yang diperoleh untuk usahatani cabai merah yang ditanam pada musim hujan $\mathrm{Rp} 37.682 .975,00$ per Hektar per musim tanam dan pada musim kemarau sebesar Rp 40.718.000,00 per Hektar per musim tanam. Terdapat perbedaan kelayakan usahatani cabai merah di musim kemarau apabila dibandingkan dengan kelayakan di musim hujan, dengan nilai $\mathrm{R}-\mathrm{C}$ ratio di musim kemarau sebesar 1,997 dan pada musim hujan sebesar 1,789. Usahatani cabai merah yang ditanam pada musim hujan dan musim kemarau layak untuk diusahakan. Untuk mengatasi permasalahan di musim hujan, Sumarni dan Muharam (2008) menyampaikan bahwa untuk menanggulangi masalah di musim hujan bisa dengan menggunakan naungan plastik ( screen plastic) dan mulsa plastik. Dengan teknologi naungan dan mulsa plastik kendalakendala yang menghadang usahatani cabai merah di musim hujan dapat dikurangi sehingga hasil kualitas hasil dan R-C Ratio cabai merah dapat ditingkatkan.
\end{abstract}

Kata kunci: cabai merah, kelayakan, usahatani, musim

\section{ABSTRACT}

The Comparative Feasibility Study of Red Chili Farming In The Different Season Cases On the Tunas Jaya Farmers Group at the village of Sukagalih Sukaratu sub district Tasikmalaya Regency. The aim of the study is to determine the costs, revenues and feasibility of the of red peppers farm planted in the wet and dry season at the village of Tunas Jaya farmers group of district Sukagalih Sukaratu Tasikmalaya regency. Method of the reaserch is a case study on Farmers Group in the village of Tunas Jaya district Sukagalih Sukaratu Tasikmalaya regency. The result of the research indicates the amount of expenses incurred in the rice farming that uses a red chili pepper plant in the rainy season is $R p 47.718 .410,00$ per hectare per growing season and on chili farms that planted in the dry season amounted to $R p$ 40.832.250,00 per growing season. The income for the farming of red chili grown on rainy season is $R p$ 37.682.975,00 per hectare per growing season while the farms that plants red peppers in the dry season is Rp 40.718.000,00 per hectare per growing season. There are differences feasibility chili farming in the dry season when compared with the 


\section{STUDI KOMPARATIF KELAYAKAN USAHATANI CABAI MERAH \\ PADA MUSIM YANG BERBEDA \\ Betty Rofatin, Jati Wijaya}

feasibility of the rainy season, the $R C$ values in the dry season ratio of 1.997 and 1.789 for the rainy season. Farming chili grown in the rainy season and dry season worth the effort. To overcome the problems in the rainy season, Sumarni and Muharam (2008) extended that to address the problem in the rainy season can by using a plastic shade (screen plastic) and plastic mulch.

Keywords: red chili, feasibility, farming, season

\section{PENDAHULUAN}

Sektor pertanian sampai saat ini dan di masa mendatang tetap memberikan kontribusi yang cukup tinggi terhadap pendapatan petani, pendapatan nasional sebagai penghasil devisa negara dan pencipta lapangan kerja bagi penduduk. Seperti yang dikemukakan Mubyarto (1989) bahwa dimasa mendatang, sektor pertanian tetap dibutuhkan atau diperlukan untuk merangsang meningkatkan pendapatan, kesempatan kerja dan taraf hidup masyarakat pedesaan, menjamin pemerataan pendapatan, mencukupi kebutuhan dalam negeri dan menghasilkan devisa bagi Negara.

Secara umum sektor pertanian terdiri dari sub sektor tanaman pangan dan hortikultura, kehutanan, perkebunan, peternakan, serta perikanan yang merupakan aspek sangat potensial untuk dikembangkan (Mubyarto, 1989). Salah satu komoditas hortikultura yang memiliki prospek untuk dikembangkan yaitu cabai merah, karena komoditas ini sangat dibutuhkan oleh hampir semua orang dari berbagai lapisan masyarakat.

Usahatani cabai merah memiliki prospek yang cukup baik untuk dikembangkan, hal ini dibuktikan dengan banyaknya permintaan cabai merah yaitu sebanyak 1.236.005 ton pada tahun 2008 dan produksi yang dihasilkan 1.310.990 pada tahun 2008. Keberhasilan usahatani sangat ditentukan oleh kemampuan petani dalam melakukan usahatani. Hal itu sejalan dengan pendapat Soekartawi,et.al. (1986), bahwa usahatani sangat ditentukan oleh kemampuan petani dalam mengatasi berbagai faktor kendala yang ada pada usahatani tersebut. Perilaku petani dalam menentukan keputusannya dibentuk oleh sikap dan persepsinya dalam mengambil keputusan dan juga dibentuk oleh faktorfaktor eksternal.

Salah satu faktor eksternal yang sangat berpengaruh terhadap usahatani cabai merah adalah cuaca. Masalah cuaca, seperti musim kemarau panjang, hujan tidak menentu serta banjir merupakan resiko alam yang seringkali dihadapi dalam usahatani cabai merah. Hal tersebut menyebabkan tingkat kerugian atau kerusakan akan bervariasi, sehingga besarnya hasil produksi cabai yang akan diperoleh petani menurun. Adapun perkembangan produksinya di 
Kabupaten Tasikmalaya pada tahun 2008

- 2009 dapat dilihat pada Gambar 1.

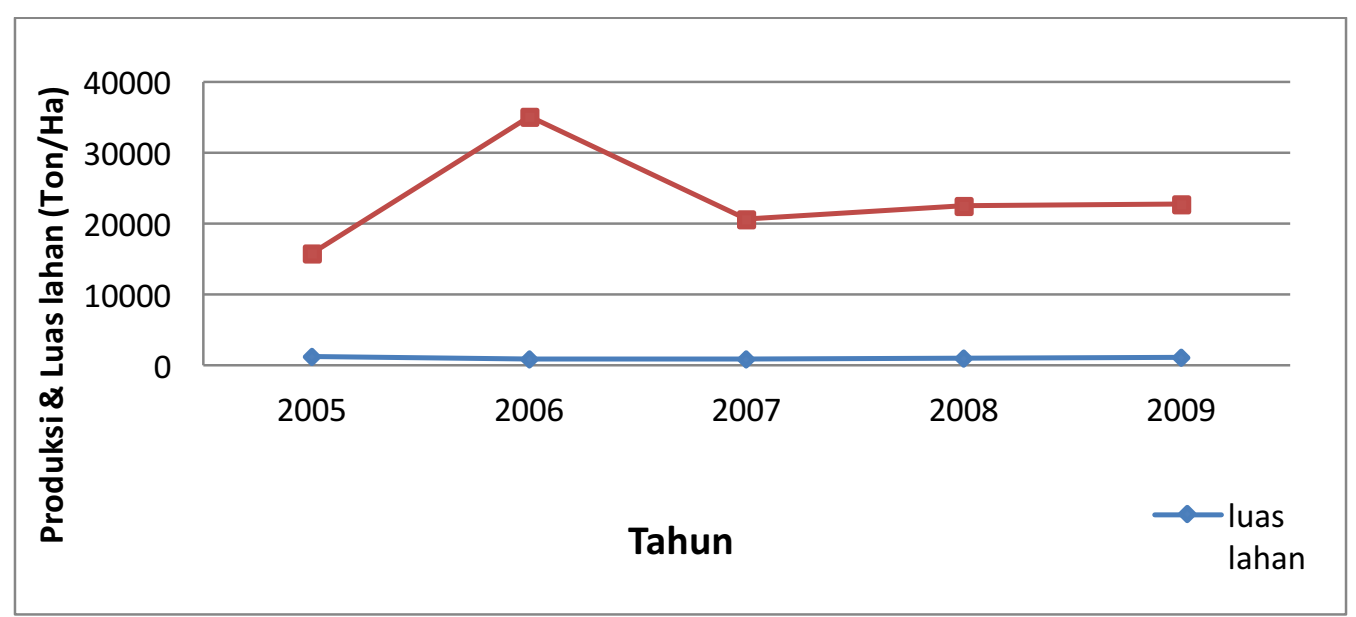

Sumber: Dinas Pertanian Tanaman Pangan dan Hortikultura Kabupaten Tasikmalaya 2011

Gambar 1. Produksi Cabai Merah di Kabupaten Tasikmalaya Tahun 2005 - 2009

Berdasarkan Gambar 1, luas lahan yang digunakan dalam usahatani cabai merah di kabupaten Tasikmalaya relatif tetap, karena petani masih kurang berani mengambil resiko untuk menambah luas usahanya. Meski lahan yang digunakan tidak bertambah, produksi cabai selalu berfluktuasi. Produksi terendah terjadi pada tahun 2005 dan produksi tertinggi terjadi pada tahun 2006, hal ini terjadi karena luas area pemanenan di tahun 2006 lebih besar dari luas area tanam (penanaman cabai merah pada tahun 2005 baru dipanen pada tahun 2006). Sedangkan pada tahun 2007 mengalami penurunan, hal ini dikarenakan adanya peristiwa alam seperti keadaan cuaca yang tidak menentu sehingga menyebabkan banyaknya serangan hama penyakit dan diperburuk dengan terjadinya kenaikan harga-harga sarana produksi pertanian. (Dinas Pertanian Kabupaten Tasikmalaya, 2010).

Umumnya usahatani cabai merah memiliki skala relatif kecil dan adanya ketergantungan terhadap harga jual yang selalu berfluktuasi setiap waktu yang akan mempengaruhi hasil usahatani serta pendapatan petani (Agung, et.al, 1999). Harga jual rata-rata cabai merah di Kabupaten Tasikmalaya tahun 2008 dan 2009 dapat dilihat pada Gambar 2. 


\section{STUDI KOMPARATIF KELAYAKAN USAHATANI CABAI MERAH \\ PADA MUSIM YANG BERBEDA \\ Betty Rofatin, Jati Wijaya}

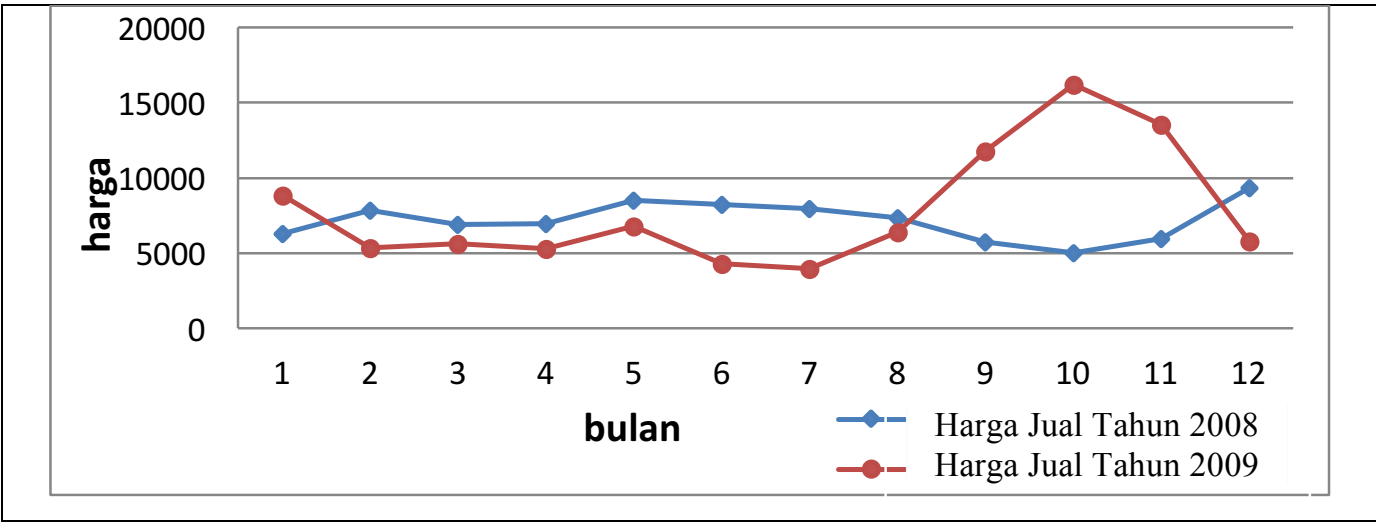

Sumber: Dinas Pertanian Tanaman Pangan dan Hortikultura Kabupaten Tasikmalaya 2011

\section{Gambar 2. Harga Jual Rata-rata Cabai Merah di Kabupaten Tasikmalaya Tahun 2008 dan 2009}

Berdasarkan Gambar 2, harga jual rata-rata cabai merah di tingkat petani per bulan selalu berfluktuasi. Fluktuasi harga merupakan faktor yang mempengaruhi pendapatan petani. Suplai cabai merah saat petani panen serentak, produksi yang tersedia dipasaran banyak sehingga harga jual menjadi murah (biasanya terjadi pada musim kemarau), sebaliknya pada saat suplai terbatas karena petani yang melakukan panen sedikit, ketersediaan cabai merah akan berkurang sehingga harga jual menjadi tinggi (biasanya terjadi pada musim hujan).

Salah satu daerah yang menghasilkan cabai merah di Kabupaten Tasikmalaya adalah Kecamatan Sukaratu khususnya di Desa Sukagalih, di daerah ini petani sudah biasa berusahatani cabai merah dan menanam cabai disetiap musim, baik musim hujan maupun musim kemarau. Hal ini dibuktikan dengan terpilihnya kelompok tani di daerah Sukagalih sebagai kelompok tani yang menerima bantuan dari pemerintah Kabupaten Tasikmalaya atas konsistensinya berbudidaya cabai.

Penanaman cabai merah dimusim hujan memiliki resiko yang tinggi, sehingga produksi yang dihasilkan rendah. Rendahnya produksi diakibatkan oleh serangan hama dan penyakit, pencucian hara, rendahnya intensitas cahaya matahari atau curah hujan tinggi. Terkait dengan hama dan penyakit penanaman di musim hujan sangat rentan terhadap serangan hama dan penyakit sehingga mengakibatkan pemakaian pestisida yang tinggi. Basuki (1988) seperti yang dikutip Sumarni dan Muharam (2008) melaporkan bahwa input terbesar dalam sistem usahatani cabai merah adalah penggunaan pestisida terutama fungisida yang dapat mencapai 40 persen. Akan tetapi dalam musim ini biasanya harga dipasaran tinggi karena kurangnya pasokan barang yang beredar. Penanaman dimusim kemarau memang cenderung menghasilkan 
produksi yang tinggi, namun tingkat harga di musim kemarau rendah yang disebabkan oleh ketidakseimbangan antara permintaan dan penawaran. Atas dasar itu penulis tertarik untuk melakukan penelitian mengenai "Studi Komparatif Kelayakan Usahatani Cabai Merah Pada Musim Yang Berbeda".

Adapun tujuan penelitian adalah untuk mengetahui besarnya biaya dan Pendapatan Usahatani Cabai Merah yang ditanam pada musim hujan dan musim kemarau dan untuk mengetahui perbedaan Kelayakan Usahatani Cabai Merah yang ditanam pada musim hujan dengan musim kemarau.

\section{METODE PENELITIAN}

Metode penelitian menggunakan metode studi kasus yang mengambil lokasi pada Kelompok Tani Tunas Jaya di Desa Sukagalih Kecamatan Sukaratu Kabupaten Tasikmalaya dengan jumlah petani sebanyak 10 orang. Pemilihan lokasi tersebut dilakukan secara sengaja (purposive) dengan pertimbangan bahwa sebagian besar petani di lokasi tersebut sudah menanam lebih dari satu periode dan merupakan pusat penanaman Cabai Merah di Kecamatan Sukaratu serta merupakan kelompok tani hortikultura pertama di Kecamatan Sukaratu.

Data yang diperlukan dan berhubungan dengan penelitian ini meliputi :
Data primer, yaitu data yang diperoleh melalui wawancara langsung dengan petani responden pelaku usahatani Cabai Merah yang ditanam pada musim hujan dengan musim kemarau sebagai responden.

Data sekunder, yaitu data yang diperoleh dari instansi-instansi atau lembaga-lembaga yang terkait serta referensi-referensi buku lain yang berkaitan dengan penelitian ini.

Gambaran teknis budidaya cabai merah dengan kondisi teknis yang muncul dijelaskan indikator secara deskriptif. Besarnya biaya, penerimaan total, Pendapatan dan R-C Ratio Usahatani Cabai Merah yang ditanam pada musim hujan dengan musim kemarau, dianalisis seperti dapat dilihat di bawah ini:

Biaya Total diperoleh dengan cara menjumlahkan total biaya tetap dengan total biaya variabel (Ken Suratiyah, 2006), dengan rumus sebagai berikut :

$$
\text { TC }=\text { TFC }+ \text { TVC }
$$

Keterangan :

$\mathrm{TC}=$ Total Cost (Biaya Total)

TFC = Total Fixed Cost

(Total Biaya Tetap)

TVC = Total Variable Cost

(Total Biaya Variabel)

Penerimaan adalah jumlah produk yang dihasilkan dikalikan harga jual persatuan produk (Ken Suratiyah, 2006). Secara umum total penerimaan dapat 


\section{STUDI KOMPARATIF KELAYAKAN USAHATANI CABAI MERAH \\ PADA MUSIM YANG BERBEDA \\ Betty Rofatin, Jati Wijaya}

dinyatakan dalam persamaan sebagai berikut :

$$
\mathbf{R}=\mathbf{Y} . \mathbf{P}
$$

Keterangan:

$\mathrm{R}=$ Revenue (Penerimaan)

$\mathrm{Y}=$ Yield atau Produksi Total $(\mathrm{kg})$

$\mathrm{P}=$ Price atau Harga Hasil Produksi

$$
\text { (Rp/kg) }
$$

Pendapatan usahatani adalah selisih antara penerimaan dengan total biaya yang telah dikeluarkan (Ken Suratiyah, 2006). Rumus yang digunakan adalah :

$$
\mathbf{I}=\mathbf{R}-\mathbf{T C}
$$

Keterangan :

$\mathrm{I}=$ Income (Pendapatan)

$\mathrm{R}=$ Revenue (Penerimaan)

$\mathrm{TC}=$ Total Cost (Biaya total)

Ken Suratiyah (2006) menyatakan, bahwa analisis R-C adalah perbandingan antara penerimaan dengan total biaya per usahatani. Analisisnya dapat dituliskan sebagai berikut :

$$
\mathrm{R}-\mathrm{C}=\frac{\text { Penerimaan } \text { Total }}{\text { Biaya } \text { Total }}
$$

Analisis R-C digunakan untuk mengetahui kelayakan usaha yang dijalankan. Adapun kriteria penilaian kelayakan tersebut yaitu :

$\mathrm{R}-\mathrm{C}=1$, Artinya usahatani Cabai Merah tidak memperoleh keuntungan atau tidak mengalami kerugian (impas).

$\mathrm{R}-\mathrm{C}<1$, Artinya usahatani Cabai Merah yang dilakukan mengalami kerugian dan tidak layak diusahakan.

$\mathrm{R}-\mathrm{C}>1$, Artinya usahatani Cabai Merah yang dilakukan memperoleh keuntungan dan layak diusahakan.

Penelitian ini dilakukan di Desa Sukagalih Kecamatan Sukaratu Kabupaten Tasikmalaya. Adapun waktu penelitian mulai bulan mei sampai oktober 2011.

HASIL DAN PEMBAHASAN

Biaya Tetap Pada Usahatani Cabai Merah yang Ditanam pada Musim Hujan dan Musim Kemarau

Pada penelitian ini yang dihitung dalam biaya tetap adalah sewa lahan, penyusutan alat dan bunga modal. Untuk lebih jelasnya lagi dapat dilihat pada Tabel 1.

Tabel 1. Rincian Jumlah Biaya Tetap pada Usahatani Cabai Merah Per Hektar Per Musim pada Petani yang Melakukan Penanaman di Musim Hujan dan Musim Kemarau

\begin{tabular}{|c|l|c|r|}
\hline \multirow{2}{*}{ No } & \multirow{2}{*}{ Uraian } & $\begin{array}{c}\text { Penanaman di } \\
\text { musim hujan }\end{array}$ & $\begin{array}{c}\text { Penanaman di } \\
\text { musim kemarau }\end{array}$ \\
\cline { 3 - 4 } & & Jumlah (Rp) & \multicolumn{1}{c|}{ Jumlah (Rp) } \\
\hline 1 & Sewa Lahan & $6.086 .600,00$ & $5.943 .050,00$ \\
2 & Penyusutan Alat & $2.380 .450,00$ & $2.103 .500,00$ \\
3 & Bunga Modal & $889.050,00$ & $844.900,00$ \\
\hline & Jumlah & $\mathbf{9 . 3 5 6 . 1 0 0 , 0 0}$ & $\mathbf{8 . 8 9 1 . 4 5 0 , 0 0}$ \\
\hline
\end{tabular}

Sumber : Data Primer Diolah 
Besarnya biaya tetap berdasarkan Tabel 5 untuk usahatani cabai merah per Hektar per Musim pada petani yang menanam pada musim hujan Rp 9.356.100,00 sedangkan biaya tetap yang dikeluarkan untuk usahatani cabai merah per Hektar per Musim pada petani yang menanam pada musim kemarau sebesar $\operatorname{Rp~8.891.450,00~dalam~biaya~}$ tetap usahatani cabai merah lebih besar biaya pada saat penanaman di musim hujan, meskipun perbedaannya tidak begitu besar. Sewa lahan pada musim hujan lebih mahal dibanding dengan di musim kemarau. Hal ini diakibatkan karena adanya persaingan dalam penggunaan untuk padi sawah. besar pada musim hujan, karena penggunaan alat-alat lebih banyak di musim hujan.

Biaya Variabel Pada Usahatani Cabai Merah yang Ditanam pada Musim Hujan dan Musim Kemarau.

Biaya variabel merupakan biaya yang besar kecilnya dipengaruhi oleh volume produksi selama satu musim tanam. Pada penghitungan biaya variabel ini beberapa jenis yaitu biaya sarana produksi yang didalamnya terdiri dari benih, pupuk, kapur, pestisida dan lainlain. Selain dari biaya sarana produksi juga dihitung biaya tenaga kerja dan bunga modal variabel. Untuk lebih jelas dapat dilihat pada Tabel 2 .

Penyusutan alat pada biaya tetap ini lebih

Tabel 2. Rincian Jumlah Biaya Variabel pada Usahatani Cabai Merah Per Hektar Per Musim pada Petani yang Melakukan Penanaman pada Musim Hujan dan Musim

Kemarau

\begin{tabular}{|c|c|c|c|}
\hline \multirow{2}{*}{ No } & \multirow{2}{*}{ Uraian } & $\begin{array}{c}\text { Penanaman di musim } \\
\text { hujan }\end{array}$ & $\begin{array}{c}\text { Penanaman di musim } \\
\text { kemarau }\end{array}$ \\
\hline & & Rata-rata jumlah (Rp) & Rata-rata jumlah (Rp) \\
\hline \multirow[t]{13}{*}{1} & $\begin{array}{c}\text { Sarana Produksi } \\
\text { - Benih }\end{array}$ & $1.032 .000,00$ & $1.008 .000,00$ \\
\hline & - Pupuk & & \\
\hline & a) Kandang & $1.400 .000,00$ & $1.565 .000,00$ \\
\hline & b) Urea & $295.000,00$ & $320.000,00$ \\
\hline & c) TSP & $487.200,00$ & $558.600,00$ \\
\hline & d) $\mathrm{KCL}$ & $447.600,00$ & $495.600,00$ \\
\hline & e) ZA & $639.100,00$ & $661.100,00$ \\
\hline & f) Phonska & $877.800,00$ & $678.300,00$ \\
\hline & - Kapur & $391.360,00$ & $401.600,00$ \\
\hline & - Pestisida & $14.506 .950,00$ & $10.348 .800,00$ \\
\hline & - Plastik & $268.250,00$ & $261.400,00$ \\
\hline & - $\quad$ MPHP & $3.051 .150,00$ & $3.030 .150,00$ \\
\hline & - $\quad$ Bambu & $80.000,00$ & $80.000,00$ \\
\hline 2 & Biaya Tenaga Kerja & $11.244 .000,00$ & $9.498 .000,00$ \\
\hline 3 & Bunga Modal & $3.641 .900,00$ & $3.034 .250,00$ \\
\hline \multicolumn{2}{|r|}{ nlah Biava Variabel } & $38.362 .310,00$ & $31.940 .800,00$ \\
\hline
\end{tabular}

Sumber : Data Primer Diolah 


\section{STUDI KOMPARATIF KELAYAKAN USAHATANI CABAI MERAH \\ PADA MUSIM YANG BERBEDA \\ Betty Rofatin, Jati Wijaya}

Pada Tabel 2 diatas menunjukan bahwa besarnya biaya variabel pada usahatani cabai merah yang dilakukan di musim hujan pada penelitian ini rata-rata sebesar Rp 38.362.310,00 dan biaya variabel pada musim kemarau rata-rata sebesar Rp 31.940.800,00. Jumlah biaya sarana produksi usaha tani cabai merah yang ditanam pada musim hujan $\mathrm{Rp}$ 22.444.410,00 dan sarana produksi usahatani cabai merah pada musim kemarau sebesar $\operatorname{Rp} 18.400 .550,00$. Biaya variabel yang digunakan selain biaya sarana produksi ada juga biaya tenaga kerja dan bunga modal variabel. Jumlah biaya tenaga kerja yang dikeluarkan pada usahatani cabai merah yang ditanam pada musim hujan $\mathrm{Rp}$ 11.244.000,00, bunga modal $R p$ $3.641 .900,00$ dan biaya tenaga kerja yang dikeluarkan pada usahatani cabai merah yang ditanam pada musim kemarau Rp 9.498.000,00 bunga modal sebesar Rp $3.034 .250,00$.

Pada biaya variabel usahatani cabai merah yang ditanam pada musim hujan dan musim kemarau yang paling terlihat perbedaannya yaitu pada penggunaan pestisida dan penggunaan tenaga kerja. Pestisida untuk usahatani cabai merah pada musim hujan sebesar Rp 14.506.950,00, biaya tenaga kerja Rp 11.244.000,00 per Hektar per Musim tanam sedangkan pestisida untuk usahatani cabai merah yang ditanam pada musim kemarau sebesar $\mathrm{Rp}$ 10.348.800,00 biaya tenaga kerja $\mathrm{Rp}$ 9.498.000,00 per Hektar per Musim tanam. Selisih biaya pestisida $R p$ 4.158.150,00 dan selisih tenaga kerja Rp 1.746.000,00.

Perbedaan biaya tersebut diakibatkan karena serangan hama maupun penyakit pada musim hujan yang tinggi, akibatnya kebutuhan pestisida seperti fungisida dan insektisida menjadi lebih tinggi. Sehingga tenaga kerja yang dibutuhkan untuk penanggulangan hama dan penyakit menjadi lebih banyak.

Biaya total dalam proses produksi usahatani cabai merah yang ditanam pada musim hujan dan pada musim kemarau merupakan hasil penjumlahan dari biaya tetap dan biaya variabel, untuk lebih jelas dapat dilihat pada Tabel 3.

Tabel 3. Rata-rata Biaya Total pada Usahatani Cabai Merah Per Hektar Per Musim pada Petani yang Menanam pada Musim Hujan dan Musim Kemarau.

\begin{tabular}{|c|l|c|r|}
\hline \multirow{2}{*}{ No } & \multirow{2}{*}{ Uraian } & $\begin{array}{c}\text { Penanaman di } \\
\text { musim hujan }\end{array}$ & $\begin{array}{c}\text { Penanaman di musim } \\
\text { kemarau }\end{array}$ \\
\cline { 3 - 4 } & & Rata-rata jumlah (Rp) & Rata-rata jumlah (Rp) \\
\hline 1 & Biaya Tetap & $9.356 .100,00$ & $8.891 .450,00$ \\
2 & Biaya Variabel & $38.362 .310,00$ & $31.940 .800,00$ \\
\hline \multicolumn{2}{|c|}{ Jumlah Biaya Total } & $\mathbf{4 7 . 7 1 8 . 4 1 0 , 0 0}$ & $\mathbf{4 0 . 8 3 2 . 2 5 0 , 0 0}$ \\
\hline
\end{tabular}

Sumber : Data Primer Yang Diolah 
Biaya total yang dikeluarkan untuk kegiatan usahatani cabai merah yang ditanam pada musim hujan per Hektar per musim tanam sebesar Rp 47.718.410,00 dan yang ditanam pada musim kemarau sebesar Rp 40.832.250,00. Biaya total lebih besar dikeluarkan pada musim hujan dengan selisih Rp 6.886.160,00. Hal ini terjadi karena biaya variabel usahatani cabai merah di musim hujan lebih besar dari musim kemarau.

\section{Penerimaan}

Penerimaan usahatani cabai merah dalam penelitian yang dilakukan di kelompok tani Tunas Jaya Desa Sukagalih Kecamatan Sukaratu Kabupaten Tasikmalaya diperoleh dari perkalian hasil produksi usahatani cabai merah yang ditanam pada musim hujan dan yang ditanam pada musim kemarau dengan harga jual. Untuk lebih jelasnya dapat dilihat pada Tabel 4 .

Tabel 4. Rata-rata Penerimaan Petani Responden pada Usahatani Cabai Merah Per Hektar Per Musim pada Petani yang Menanam pada Musim Hujan dan Musim Kemarau.

\begin{tabular}{|c|l|c|c|c|}
\hline No & Uraian & $\begin{array}{c}\text { Produksi } \\
\text { rata-rata } \\
\mathbf{( k g )}\end{array}$ & $\begin{array}{c}\text { Harga } \\
\text { rata-rata } \\
\mathbf{( R \mathbf { R } )}\end{array}$ & $\begin{array}{c}\text { Penerimaan } \\
\text { rata-rata } \\
\mathbf{( R \mathbf { p } )}\end{array}$ \\
\hline 1 & Penanaman di musim hujan & $8.958,50$ & $9.533,01$ & $\mathbf{8 5 . 4 0 1 . 3 8 5 , 0 0}$ \\
\hline 2 & Penanaman di musim kemarau & $13.322,50$ & $6.121,25$ & $\mathbf{8 1 . 5 5 0 . 2 5 0 , 0 0}$ \\
\hline
\end{tabular}

Sumber : Data Primer Yang Diolah

Besarnya penerimaan yang diperoleh petani cabai merah yang menanam di musim hujan adalah $\mathrm{Rp}$ 85.401.385,00 per Hektar per Musim dan penerimaan yang diperoleh petani yang menanam di musim kemarau sebesar Rp 81.550.250,00 per Hekta per Musim. Hasil yang diperoleh pada musim kemarau lebih tinggi dari produksi pada musim hujan, akan tetapi harga jual pada musim hujan lebih tinggi dibanding dengan musim kemarau.

Perbedaan harga terjadi karena ketersediaan cabai merah di pasaran berbeda. Pada saat panen serentak biasanya pada musim kemarau cabai yang beredar banyak sementara permintaan terbatas, sehingga harga menjadi murah. Sebaliknya di musim hujan ketersediaan cabai merah di pasaran sedikit sementara permintaan banyak, hal ini yang menyebabkan harga cabai menjadi mahal. Harga cabai merah di musim kemarau pada saat penelitian berkisar antara Rp 3.500,00- Rp 8.200,00 dan harga cabai di musim Hujan berkisar antara Rp 6.250,00- Rp 16.000,00.

\section{Pendapatan}

Pendapatan usahatani cabai merah yang ditanam pada musim hujan dan yang ditanam pada musim kemarau diperoleh dari hasil penerimaan dikurangi dengan biaya total produksi per Hektar 


\section{STUDI KOMPARATIF KELAYAKAN USAHATANI CABAI MERAH \\ PADA MUSIM YANG BERBEDA \\ Betty Rofatin, Jati Wijaya}

per Musim tanam. Untuk lebih jelas dapat

dilihat pada Tabel 5.

Tabel 5. Rata-rata Pendapatan Petani Responden pada Usahatani Cabai Merah Per Hektar Per Musim pada Petani yang Menanam pada Musim Hujan dan Musim Kemarau.

\begin{tabular}{|c|l|r|r|}
\hline \multirow{2}{*}{ No } & \multicolumn{1}{|c|}{ Uraian } & \multicolumn{1}{c|}{$\begin{array}{c}\text { Penanaman di } \\
\text { musim hujan }\end{array}$} & $\begin{array}{c}\text { Penanaman di musim } \\
\text { kemarau }\end{array}$ \\
\cline { 3 - 4 } & & Jumlah (Rp) & \multicolumn{1}{c|}{ Jumlah (Rp) } \\
\hline 1 & Penerimaan & $85.401 .385,00$ & $81.550 .250,00$ \\
2 & Biaya Total & $47.718 .410,00$ & $40.832 .250,00$ \\
3 & Pendapatan & $37.682 .975,00$ & $40.718 .000,00$ \\
4 & R-C Ratio & 1,789 & 1,997 \\
\hline
\end{tabular}

Sumber : Data Primer Yang Diolah

Pendapatan petani yang diperoleh pada usahatani cabai Merah per Hektar Per Musim pada petani yang menanam pada musim hujan dan musim kemarau pada penelitian ini lebih besar diperoleh pada penanaman di musim kemarau dengan selisih $\operatorname{Rp} 3.035 .025,00$ per Hektar per musim tanam.

\section{R-C Ratio}

R-C merupakan perbandingan antara hasil penerimaan dengan biaya total produksi. Berdasarkan Tabel 9, R-C ratio pada usahatani cabai merah yang ditanam pada musim hujan 1,789. Artinya bahwa setiap 1 rupiah yang dikeluarkan akan menghasilkan penerimaan sebesar 1,789 rupiah. $\mathrm{R}-\mathrm{C}$ ratio pada usahatani cabai merah yang ditanam pada musim kemarau diperoleh nilai $\mathrm{R}-\mathrm{C}$ ratio sebasar 1,997. Artinya bahwa setiap 1 rupiah yang dikeluarkan akan menghasilkan penerimaan sebesar 1,997 rupiah.

Usahatani cabai merah yang ditanam pada musim hujan dan yang ditanam pada musim kemarau layak diusahakan, akan tetapi apabila dibandingkan maka usahatani pada musim kemarau memberikan kemungkinan lebih baik, karena produksi yang dihasilkan lebih tinggi dan biaya yang dikeluarkan lebih rendah sebagai akibat minimnya penggunaan pestisida dan tenaga kerjanya.

\section{KESIMPULAN}

Berdasarkan hasil penelitian yang dilakukan dan pembahasan, maka dapat ditarik kesimpulan sebagai berikut:

1) Biaya total yang dikeluarkan pada usahatani cabai merah per hektar per satu musim tanam yang ditanam pada musim hujan sebesar Rp 47.718.410 dan pada usahatani cabai merah yang ditanam pada musim kemarau Rp 40.832.250. Pendapatan usahatani cabai merah per hektar per musim tanam yang ditanam pada musim hujan sebesar Rp 37.682.975 sedangkan untuk usahatani cabai merah yang 
ditanam pada musim kemarau sebesar Rp 40.718.000.

2) Terdapat perbedaan kelayakan usahatani cabai merah di musim kemarau apabila dibandingkan dengan kelayakan di musim hujan, dengan nilai $\mathrm{R}-\mathrm{C}$ ratio di musim kemarau sebesar 1,997 dan pada musim hujan sebesar 1,789.

Usahatani cabai merah yang ditanam pada musim hujan dan musim kemarau layak untuk diusahakan.

\section{DAFTAR PUSTAKA}

Agromedia, Redaksi. 2007. Budidaya Cabai Hibrida. PT Agromedia Pustaka. Jakarta

Bayong Tjasyono, H.K. 2004. Klimatologi. ITB. Bandung

Desa Sukagalih, Profil Desa Sukagalih Kecamatan Sukaratu Kabupaten Tasikmalaya, 2010

Final Prajnanta. 2007. Agribisnis Cabai Hibrida. Penebar Swadaya. Jakarta http://ejournal.unud.ac.id/abstrak/(8) soca-agung dkk-analisis usahatani cabai merah(1).pdf (diakses tanggal 23 Maret 2011)
Ken Suratiyah. 2008. Ilmu Usahatani. Penebar Swadya. Jakarta

Mosher, A.T. 1991. Menggerakkan dan Membangun Pertanian. Yasaguna. Jakarta

Mubyarto. 1989. Pengantar Ekonomi Pertanian. LP3ES. Jakarta

Nani Sumarni dan A. Muharam. 2008. Sukses Bertanam Cabai Dimusim Hujan dan Kemarau. Balitsa dengan Papas Sinar Sinanti, anggota Ikapi. Jakarta

Nur Tjahjadi. 1989. Hama dan Penyakit Tanaman. Kanisius. Yogyakarta

Said Rusli. 1984. Pengantar IImu Kependudukan. LP3ES. Jakarta

Sajogyo, Pudjiwati Sajogyo. 1999. Sosiologi Pedesaan jilid 2. Gadjah Mada University Press. Yogyakarta

Soekartawi, A. Soeharja, John L. Dillon, J. Brian Hardaker. 1986. IImu Usahatani dan Penelitian Untuk Pengembangan Petani Kecil. Universitas Indonesia. Jakarta

Soekartawi, Rusmadi, E. Damaijati. 1993. Risiko dan Ketidakpastian dalam Agribisnis. PT RajaGrafindo Persada. Jakarta

Sudjana. 1989.Metode Statistika. Tarsito. Bandung

Totok Mardikanto. 1990. Pembangunan Pertanian. Tri Tunggal Tata Fajar. Surakarta 